\title{
BIOAKTIVITAS KITOOLIGOSAKARIDA YANG DIPRODUKSI DARI KITOSAN MENGGUNAKAN KITOSANASE Microminospora T5a1 SEBAGAI ANTIKAPANG
}

\section{Bioactivity of Chitooligosaccharide Produced by Chitosan using Microminospora T5a1 Chitosanase as Antifungal}

\author{
Ekowati Chasanah ${ }^{1 *}$, Yusro Nuri Fawzya ${ }^{1}$, Fiona Ariani K. ${ }^{2}$ dan Maruli S. ${ }^{2}$ \\ ${ }^{1}$ Balai Besar Penelitian dan Pengembangan Pengolahan Produk dan Bioteknologi Kelautan dan Perikanan, KKP. \\ JI. K.S.Tubun Petamburan VI, Jakarta Pusat 10260 \\ 2 Swiss German University, Serpong \\ * Korespondensi Penulis: ekowatichasanah@gmail.com
}

Diterima: 24 Juli 2012, Disetujui: 24 Mei 2013

\begin{abstract}
ABSTRAK
Penelitian ini bertujuan untuk menguji kitooligosakarida (COS) yang diproduksi secara biologi menggunakan kitosanase dari Microminospora T5a1 terhadap kapang perusak dan penghasil toksin pada makanan. Kitooligosakarida diuji dengan konsentrasi 250-1000 ppm, dan sebagai kontrol positif telah digunakan produk antikapang komersial yaitu Na-benzoat dan K-sorbat pada konsentrasi aplikasi komersial 1000 ppm serta kitosan pada konsentrasi uji sama seperti COS. Kapang yang digunakan adalah Aspergillus flavus, Aspergillus niger dan Penicillium sp. Hasil penelitian menunjukkan bahwa kemampuan penghambatan kapang oleh COS tidak linear dengan konsentrasi yang diaplikasikan. Untuk Aspergillus flavus, penghambatan terbaik diperoleh pada aplikasi COS 250 ppm, sedangkan untuk Aspergillus niger dan Penicillium A12 dengan konsentrasi 750 dan 500 ppm. Kitosan memiliki aktivitas penghambatan yang sama dengan COS untuk ketiga kapang uji. Dibandingkan dengan kontrol positif, COS memiliki aktivitas antikapang yang tidak berbeda dengan sodium benzoate dan potasium sorbate, sehingga COS yang dihasilkan berpotensi digunakan sebagai pengganti ke dua produk komersial tersebut, dengan konsentrasi yang lebih rendah.
\end{abstract}

KATAKUNCl: kitooligosakarida, produksi secara enzimatis, Microminospora T5a1, anti kapang

\begin{abstract}
This research was intended to assess the bioactivity of chitooligosaccharide (COS) biologically produced using Microminospora T5a1 chitosanase against food borne and toxin producing fungi. The COS has been tested in concentration of 250-1000 ppm, and positive control of Na-benzoate and $\mathrm{K}$-sorbate in their commercial application of $1000 \mathrm{ppm}$ were used as well as chitosan in the same concentration of COS. Results showed that the COS had ability to inhibit all of the fungi, albeit at a certain concentration, not linear with the concentration of COS applied. The best inhibition concentration for Aspergillus flavus, Aspergillus niger and Penicillium A12 were 250, 750 and 500 ppm respectively. Chitosan had analogous inhibition activity with COS for almost all foodborne fungi tested. Comparing COS with positive control, it was found out that there were no significant differences between them. It means that the COS could be used as replacement of commercially, sinthetic antifungi substaces of sodium benzoate and potassium sorbate in lower concentration.
\end{abstract}

KEYWORDS: chitooligosaccharide, enzymatically produced, Microminospora T5a1, antifungi

\section{PENDAHULUAN}

Serangan mikroba merupakan salah satu penyebab susut hasil pada produk perikanan dan pertanian lain di Indonesia, bahkan dapat menjadi penyebab keracunan atau sakit pada konsumen pengkonsumsi produk yang terkontaminasi mikroba patogen. Ikan dan produk olahannya merupakan komoditas penting untuk penduduk Indonesia, baik untuk konsumsi lokal maupun sebagai komoditas eksport penghasil devisa. Menurut Badan POM, di antara produk-produk perikanan tradisional dari Indonesia seperti ikan asin dan pindang merupakan produk yang perlu mendapat prioritas utama untuk 
dikontrol. Produk tersebut memiliki peranan yang sangat strategis dalam ketahanan pangan masyarakat karena tingginya tingkat konsumsi masyarakat akan produk olahan ini (Rahayu, 2010), sementara produk ini sangat sensitif terhadap kerusakan mikroba terutama oleh kapang. Indriati et al. (2008) melaporkan bahwa Aspergillus flavus, $A$. niger, A. ochraniceus, Penicillium crysogenum and Rhizopus oryzae telah diisolasi dan diidentifikasi sebagai kapang yang mengkontaminasi produk pindang ikan cakalang, sementara Aspergillus juga dilaporkan sebagai kapang utama yang ditemukan dalam ikan asin.

Secara komersial, bahan tambahan yang digunakan untuk mencegah pertumbuhan kapang adalah potasium sorbat dan sodium sorbat. Bahan tersebut meskipun telah diijinkan penggunaannya ternyata memiliki efek negatif, di antaranya efeknya terhadap DNA. Potassium sorbate diklasifikasikan sebagai genotoxic (toksik terhadap DNA) terhadap human peripheral blood lymphocytes dan memiliki efek negatif terhadap imunitas (Mamur et al., 2010). Karena itu, eksplorasi bahan alami pengganti produk pengawet yang secara umum diproduksi secara kimia seperti halnya potasium dan sodium yang berfungsi sebagai pengawet sangat diperlukan. Salah satu bahan aktif yang dikenal memiliki bioaktivitas luas adalah produk turunan kitin, yaitu kitosan. Aplikasi produk ini sebagai agen biokontrol untuk kapang dan insekta telah dikenal luas di bidang pertanian (Chien et al., 2005). Aplikasi penggunaan kitosan untuk memperpanjang masa simpan pindang telah dilaporkan oleh Ariyani \& Yennie (2008), yang dapat memperpanjang masa simpan pindang ikan dari 1 hari menjadi 3 hari. Aplikasi kitosan untuk mengawetkan ikan segar telah dilaporkan oleh Hardjito (2006) dan Murtini \& Kusmarwati (2006), demikian juga untuk ikan asin oleh Hardjito (2006). Meskipun berpotensi sebagai pengawet produk ikan, aplikasi kitosan memiliki kelemahan dalam hal penerimaan produk secara sensoris. Hal ini dikarenakan kitosan hanya dapat larut dalam asam asetat, karena itu asam asetat selanjutnya akan mempengaruhi flavor produk yang diberi perlakuan kitosan. Hidrolisis kitosan menjadi produk dengan rantai lebih pendek atau kitosan dengan berat molekul rendah yang bersifat lebih larut air adalah merupakan hal yang diperlukan untuk mengatasi hal tersebut.

Penelitian terdahulu menghasilkan teknik produksi pembuatan COS atau kitosan oligomer secara enzimatis menggunakan enzim kitosanase kasar dari Stenotrophomonas malthopilia KPU 2123 (Chasanah et al., 2011). Teknik produksi ini digunakan untuk memproduksi kitooligosakarida dengan menggunakan enzim dari Micromonospora sp T5a1 (Patantis et al.,
2012) yang diisolasi dari terasi yang dibuat dari udang kecil (Zilda et al., 2006). Bakteri ini tidak patogen dan telah digunakan untuk memproduksi enzim kitinolitik di medium kitin (Noviendri et al., 2008).

Penelitian ini bertujuan untuk menguji bioaktivitas COS yang dihasilkan terhadap 3 jenis kapang perusak produk perikanan dan produk pertanian, dibandingkan dengan bioaktivitas kitosan dan produk komersial anti kapang untuk pangan.

\section{BAHAN DAN METODE}

\section{Mikroorganisma}

Microminospora T5a1 disegarkan dan dikultivasi untuk memproduksi enzim kitosanase kasar, dalam medium cair MSM (minimal sinthetic media) yang diperkaya kitin menggunakan fermentor dengan volume kerja 3L. Kapang Aspergillus flavus, Aspergillus niger dan Penicillium A12 merupakan koleksi Laboratorium mikrobiologi BBP4B-KP, diisolasi dari ikan pindang dan ikan asin (Indriati et al., 2008). Kapang-kapang tersebut di segarkan dengan Malt Extract Agar (MEA).

\section{Kitooligosakarida (COS)}

Kitooligosakarida disiapkan dengan menghidrolisis kitosan dengan enzim kitosanase kasar yang diproduksi oleh isolat T5a1 dengan konsentrasi 8U/ gram kitosan selama 8 jam (Patantis et al., 2012). Reaksi dihentikan dengan pendidihan selama 15 menit, disentrifugasi dan larutan di freezed dry. Sebelum diaplikasikan, larutan COS disterilkan dengan membran yang memiliki pori 0,22 $\mu \mathrm{M}$ atau dengan autoclave bersuhu $121^{\circ} \mathrm{C}$ selama 15 menit. Cara sterilisasi COS ini merupakan hasil penelitian pendahuluan, yang memperlihatkan bahwa COS sebaiknya disiapkan dalam bentuk larutan untuk disterilkan. Dalam bentuk bubuk dan disterilisasi, COS akan lebih sulit dilarutkan. Cara sterilisasi dengan membran berpori 0,22 $\mu \mathrm{M}$ dan autoclave yang dicobakan memberikan hasil yang tidak berbeda, mampu memberikan efek hambatan yang sama, dibandingkan dengan kontrol negatifnya.

\section{Kitosan}

Kitosan yang digunakan untuk pengujian maupun yang dipakai untuk membuat COS adalah kitosan yang memiliki DD 51,44\% (berdasarkan metoda FTIR). Sebagai perbandingan, produk komersial kitosan dari Sigma yang disebutkan memiliki DD 85\%, ketika diukur dengan metoda yang sama menggunakan FTIR memiliki DD 52,32\%. 


\section{Pengujian Anti Kapang}

Pengujian anti kapang dilakukan dengan teknik Radial Growth (Zambonelli et al., 1996). Kapang yang telah disegarkan, diinkubasi pada suhu ruang $\left(25^{\circ} \mathrm{C}\right)$ selama 5 hari, dihomogenisasi dengan larutan Tween agar (campuran tween-agar dengan komposisi 0,05\% (v/v) Tween 80 dan 0,2\% (w/v) agar, disterilkan). Setelah dihomogenisasi, spora kapang ditanam dengan menggunakan jarum steril yang ditusukkan ditengah media MEA yang telah dicampur dengan COS di cawan petri. Konsentrasi $\mathrm{COS}$ yang digunakan adalah $0,250,500,750,1000$ ppm. Inkubasi dilakukan pada suhu ruang $\left(25^{\circ} \mathrm{C}\right)$ selama 3 hari secara aseptis. Pertumbuhan kapang yang didekati dari pertambahan diameter kapang diukur dengan vernier caliper. Kontrol positif adalah potasium sorbat dan sodium benzoat. Penghambatan pertumbuhan dihitung dengan rumus: Penghambatan pertumbuhan $(\%)=((\mathrm{C}-\mathrm{T}) / \mathrm{C})^{*} 100$; di mana $\mathrm{C}$ adalah pertumbuhan tanpa perlakuan, $\mathrm{T}$ adalah pertumbuhan dengan perlakuan COS negatif. Semua perlakuan dilakukan dalam 3 kali ulangan.

\section{Analisis Data}

Data dianalisis dengan ANOVA satu faktor dan ttest. Perbedaan secara nyata dilakukan dengan selang kepercayaan 95\% (á=5\%) (Sudjana, 1996).

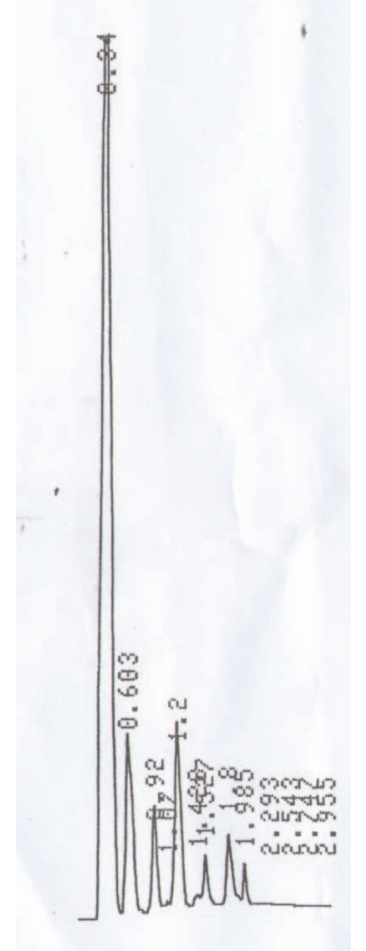

(A)

\section{HASIL DAN BAHASAN}

Gambar 1 memperlihatkan konfirmasi hasil kerja enzim kitosanase dari Microminospora T5a1 yang diisolasi dari produk olahan tradisional terasi. Kitooligosakarida yang dihasilkan merupakan campuran COS berbagai rantai.

Hasil pengujian penggunaan COS tersebut menunjukkan bahwa COS yang dihasilkan berpotensi sebagai antikapang. Kitooligosakarida dan bentuk polimernya, kitosan, keduanya tidak memberikan perbedaan nyata dalam menghambat ketiga kapang yang diuji. Ketika konsentrasi COS yang digunakan adalah 250-1000 ppm, konsentrasi optimal untuk menghambat Aspergillus flavus adalah 250-ppm, yang menunjukkan perbedaan nyata dengan kontrol negatif, sebaliknya konsentrasi aplikasi 500, 750, dan 1000 ppm tidak menunjukkan perbedaan yang nyata dengan kontrol negatif. Dibandingkan dengan kontrol positif, sodium benzoat dan potasium sorbat (1000 ppm), perlakuan COS $250 \mathrm{ppm}$ memberikan hasil yang berbeda nyata dan lebih baik (Gambar 2). Dibandingkan dengan kitosan pada konsentrasi yang sama yaitu $250 \mathrm{ppm}$, efek penghambatan COS terlihat lebih baik dibanding kitosan (Gambar 3).

Kemampuan COS dalam menghambat Aspergillus niger dapat dilihat pada Gambar 4. Dari uji statistik

Gambar 1. Hasil HPLC kitooligosakarida standar (A) dan COS dari Micromonospora T5a1 (B).

Figure 1. Results of chitooligosaccharide HPLC standard (A) and COS from Micromonospora T5a1 (B). 


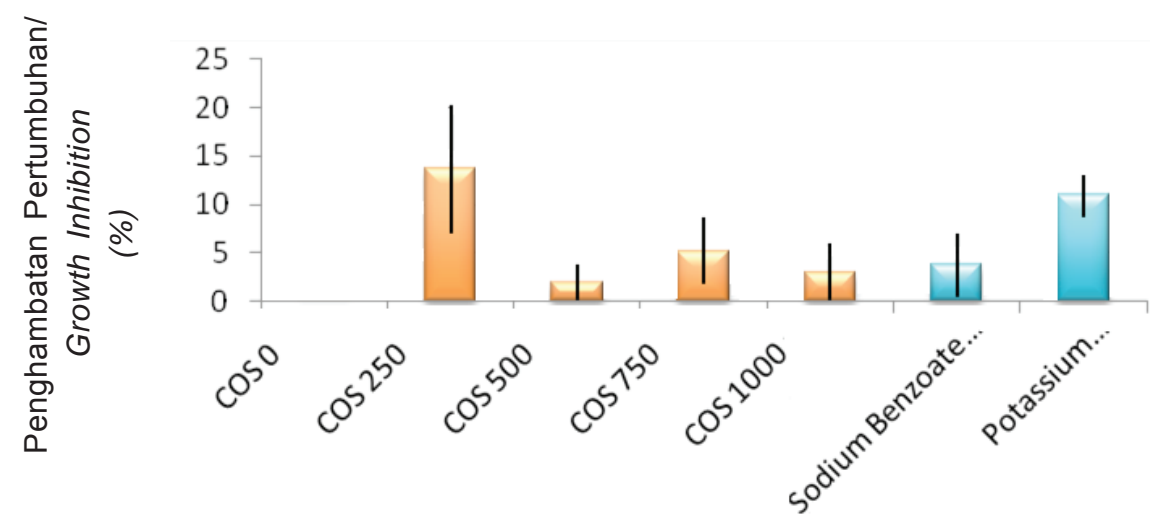

Perlakuan/Treatments

Gambar 2. Penghambatan pertumbuhan Aspergillus flavus pada berbagai konsentrasi (ppm) kitooligosakarida, kontrol negatif dan kontrol positif

Figure 2. Growth inhibition of Aspergillus flavus at various concentration of chitooligosaccharide, negative control and positive control

didapatkan bahwa antar perlakuan COS (konsentrasi 0, 250, 500, 750 dan $1000 \mathrm{ppm}$ ) terdapat perbedaan yang signifikan dalam kemampuan penghambatan pertumbuhan $A$. niger. Kitooligosakarida mampu menghambat Aspergillus niger secara maksimal pada konsentrasi 750 ppm (Gambar 4). Ketika dibandingkan dengan kontrol positif, aplikasi COS 750 dan 1000 ppm memberikan penghambatan yang tidak berbeda secara signifikan, yang mengindikasikan bahwa COS pada konsentrasi tersebut dapat digunakan sebagai substitusi produk komersial antikapang yaitu sodium benzoat dan potasium sorbat. Pada konsentrasi optimum penghambatan oleh COS tersebut (750 ppm), kitosan memperlihatkan penghambatan yang tidak sebaik COS (Gambar 5).
Penghambatan pertumbuhan kapang Penicillium sp oleh COS sebesar 250, 500, 750 dan 1000 ppm, dapat dilihat pada Gambar 6 dengan penghambatan maksimal pada aplikasi 500 ppm. Dibandingkan dengan kitosan, aplikasi COS memperlihatkan efek penghambatan yang tidak berbeda nyata $(p>0,05)$ (Gambar 6), dan ketika dibandingkan dengan kontrol positif sodium benzoat dan potasium sorbat, perlakuan COS 500 ppm memperlihatkan tidak ada perbedaan penghambatan yang nyata dengan keduanya yang berarti bahwa COS dengan konsentrasi 500 ppm dapat berpotensi sebagai pengganti pengawet kapang komersial tersebut.

Dari hasil di atas terlihat bahwa cos memperlihatkan penghambatan antikapang yang relatif
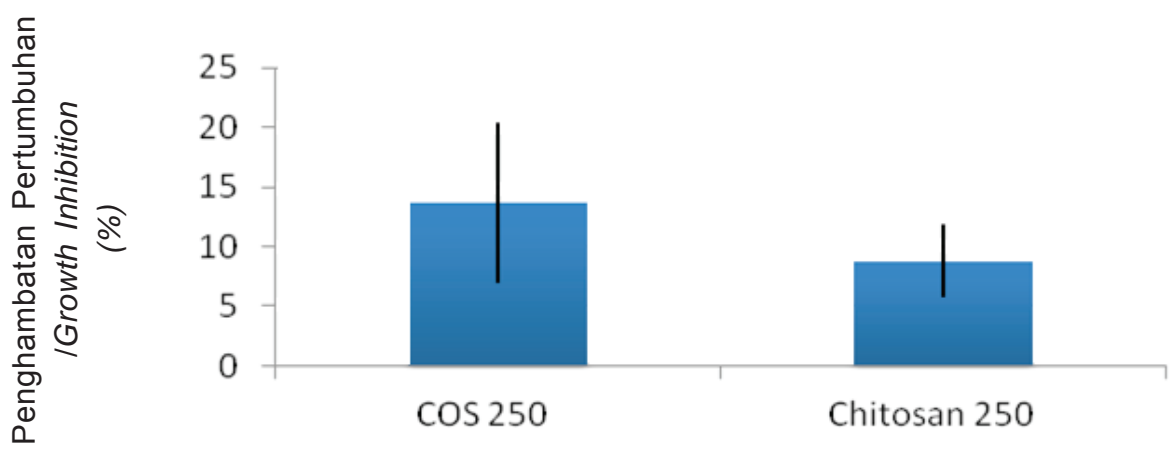

Perlakuan/Treatments

Gambar 3. Penghambatan A. flavus oleh kitosan dan kitooligosakarida pada konsentrasi optimal penghambatan.

Figure 3. Growth inhibition of Aspergillus flavus at the optimal inhibition concentration of chitooligosaccharide and chitosan. 


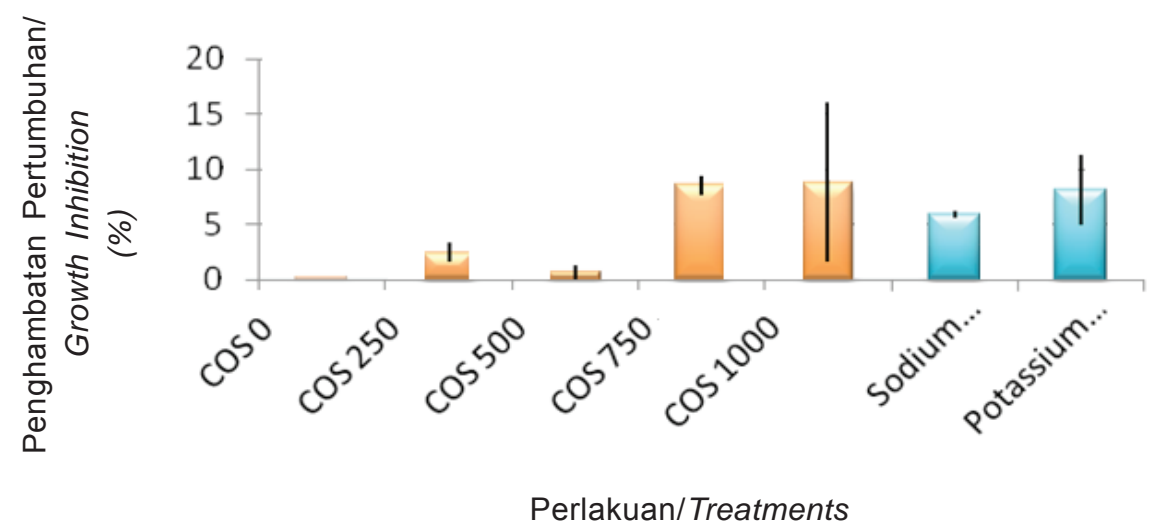

Gambar 4. Penghambatan pertumbuhan Aspergillus niger oleh kitooligosakarida pada berbagai konsentrasi (ppm), kontrol negatif dan kontrol positif

Figure 4. Growth inhibition of Aspergillus niger by various concentration of chitooligosaccharide (ppm), negative control and positive control
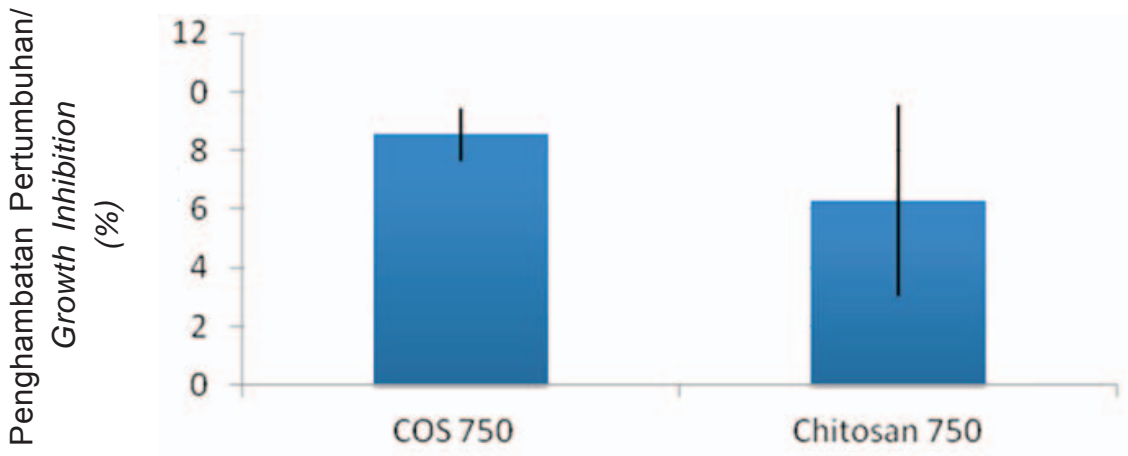

Perlakuan/Treatments

Gambar 5. Penghambatan A. niger oleh kitosan dan kitooligosakarida pada konsentrasi optimal penghambatan. Figure 5. Growth inhibition of $\boldsymbol{A}$. niger at the optimal inhibition concentration.

lebih baik dibanding bentuk polimernya yaitu kitosan (Gambar 3 dan 5 ). Kitooligosakarida didefinisikan sebagai homo atau heterooligomer $\mathrm{N}$ acetyglucosamine dan D-glucosamine (Aam, et al., 2010). Kitosan yang digunakan sebagai bahan baku untuk memproduksi COS dalam penelitian ini adalah kitosan komersial yang diproduksi unit komersial IPB yang memiliki derajat deasetilasi (DD) 51,44\% (menggunakan FTIR). Pengukuran dengan alat yang sama pada produk komersial yang diproduksi Sigma-Aldrich Corporation, yang diklaim memiliki DD 85\% (berdasarkan FDUV-spectrophotometry), menghasilkan DD sebesar 52,32\%. Karena itu dapat diperkirakan bahwa kitosan IPB yang digunakan memiliki DD yang seimbang dengan kitosan komersial
Sigma, yang merupakan polimer dengan unit campuran asetylglucosamine dan D-glucosamine, sehingga COS yang dihasilkannyapun merupakan campuran unit-unit tersebut. Derajat deasetilasi yang tinggi merupakan hal yang penting untuk bioaktivitas kitosan dan produk turunannya seperti COS. Semakin tinggi derajat deasetilasi, semakin banyak gugus aktif (asam amino dengan gugus amin positif) yang dimiliki oleh polimer dan oligomernya (COS) sehingga semakin tinggi bioaktivitasnya. Pada penelitian ini, DD yang dimiliki COS relatif sama dengan DD kitosan.

Selain tingkat DDnya, berat molekul juga menentukan tingkat keaktifan kitosan dan turunannya. Li et al. (2008) memperkirakan bahwa semakin rendah berat molekul kitosan (kitosan yang memiliki berat 


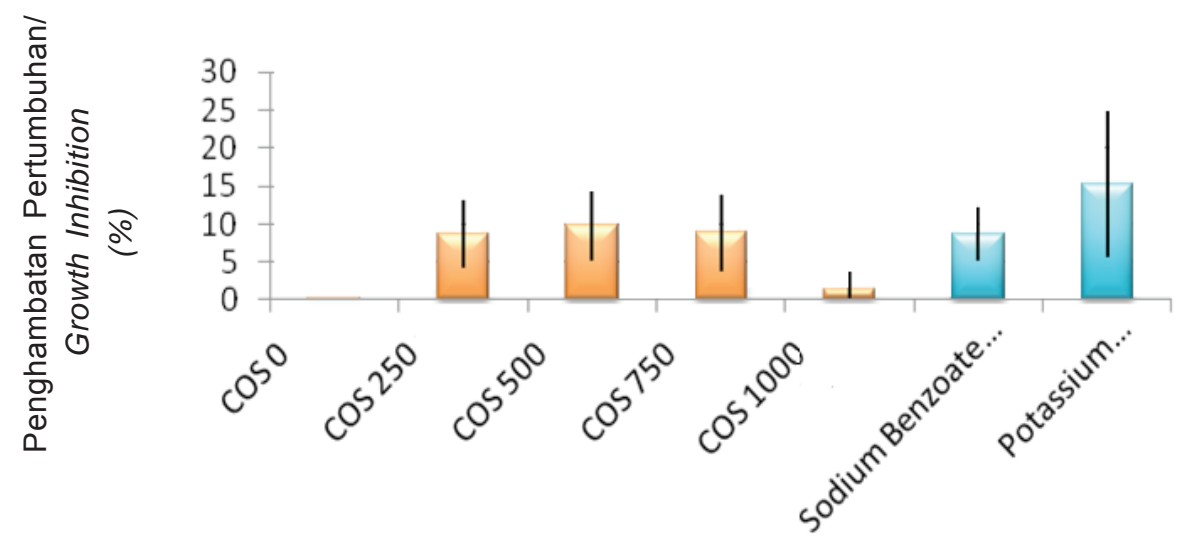

Perlakuan/Treatments

Gambar 6. Penghambatan pertumbuhan Penicillium sp. oleh kiooligosakarida pada berbagai konsentrasi (ppm), kontrol negatif dan kontrol positif.

Figure 6. Growth inhibition of Penicillium sp. at various concentration of chitooligosaccharide (ppm), negative control and positive control.

molekul rendah disini disebut kitooligosakarida), semakin tinggi bioaktivitas antikapang. Di penelitian ini, COS yang terbentuk setelah proses pemotongan kitosan oleh kitosanase kasar dari Micromonospora T5a1 selama 8 jam, yaitu COS yang memiliki campuran panjang 2-6 unit (Gambar 1). Menurut Xu et al. (2006), COS yang diproduksi secara enzimatis dan memiliki campuran panjang rantai 3-9 unit memiliki kemampuan menghambat pertumbuhan miselia kapang. COS dengan berat molekul rendah akan meningkatkan kemampuan COS sampai ke nukleus sel, berikatan dengan DNA sel dan memberikan penghambatan pembentukan mRNA dan sintesis protein (Sebti et al., 2005). Semakin kecil ukuran berat molekul kitosan atau COS, akan semakin besar aktivitas antimikrobanya. Karena itu, salah satu alasan yang memperkuat hasil bioaktivitas COS yang lebih baik dibanding kitosan adalah ukuran berat molekulnya yang lebih kecil. Dalam riset ini terlihat bahwa aktivitas penghambatan kapang terlihat lebih besar ketika digunakan COS (kitosan berat molekul rendah) dibanding bentuk polimer kitosan (Gambar 3 dan 5). Secara statistik, COS mampu menghambat Aspergillus niger dan A. flavus lebih baik dari pada kitosan tetapi tidak ada perbedaan signifikan antar keduanya dalam menghambat Penicillium A 12 $(p>0,05)$.

Mekanisme penghambatan kapang $A$. niger oleh COS yang dilaporkan oleh Li et al. (2008) adalah

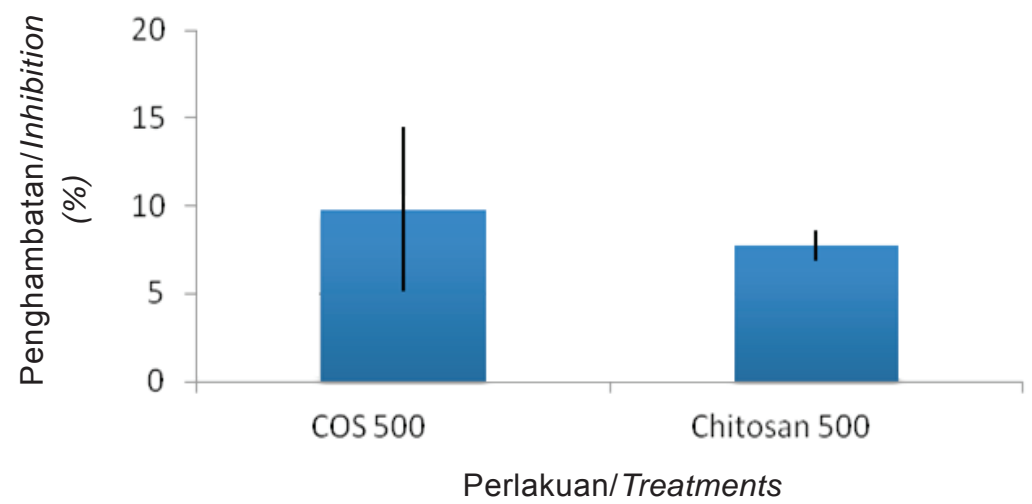

Gambar 7. Penghambatan Penicillium sp. oleh kitosan dan kitooligosakarida pada konsentrasi optimal penghambatan.

Figure 7. Growth inhibition of Penicillium sp. at the optimal inhibition concentration. 
dengan menghambat perkembangan spora kapang, utamanya melalui menghambat proses transkripsi DNA menjadi RNA. Laporan lain menyebutkan bahwa mekanisme anti kapang dari COS adalah disebabkan oleh interaksi kitosan (gugus aktifnya $-\mathrm{NH}_{2}{ }^{+}$) dengan lipid di plasma membran yang menyebabkan perubahan morfologi dan gangguan permukaan sel kapang. Komposisi plasma membran diduga memegang peranan penting dalam menentukan kesensitifitasan kapang terhadap kitosan, yang mana, semakin tinggi jumlah asam lemak tidak jenuh di plasma membran akan membuat kapang semakin sensitif (Palma-Guerrero dalam Aam et al., 2010). Hal ini yang diduga merupakan alasan respon kapang dari jenis Aspergillus yang berbeda dengan Penicillium yang digunakan dalam penelitian ini.

Kemampuan penghambatan kapang oleh COS dalam penelitian ini tidak berlifat linear dengan konsentrasi yang digunakan. Hasil penelitian yang lalu menggunakan konsentrasi 50-200 ppm, menghasilkan penghambatan yang linier dan penghambatan terbaik ditunjukkan pada aplikasi terbesar, konsentrasi 200 ppm (Chasanah et al., 2011). Pada penelitian ini, digunakan COS konsentrasi 250-1000 ppm, dan ternyata penghambatan bersifat spesifik untuk setiap kapang dan tidak bersifat linier dengan konsentrasi COS yang diberikan. Dalam riset ini (menggunakan COS berukuran 2-6 unit), penghambatan maksimal untuk $A$. flavus, A.niger dan Penicillium sp.A 12 masing-masing pada konsentrasi 250,750 , dan 500 ppm. Penghambatan oleh COS atau kitosan dengan berat molekul rendah yang tidak bersifat linear ini sejalan dengan hasil penelitian Li et al. (2008). Telah disampaikan bahwa muatan polikation $\left(\mathrm{NH}_{2}{ }^{+}\right)$ merupakan salah satu kunci bioaktivitas kitosan dan produk turunannya. Namun demikian, penggunaan konsentrasi yang lebih besar dari konsentrasi optimalnya, tidak menghasilkan penghambatan yang lebih baik seperti yang terjadi pada penelitian ini. Diduga bahwa ketika jumlah gugus - $\mathrm{NH}_{2}$ meningkat, melebihi konsentrasi yang cukup untuk penghambatan, gugus-gugus tersebut akan mendorong terbentuknya struktur ikatan semu (fictious cross-linked) melalui ikatan hidrogen yang kuat dalam molekul tersebut sehingga gugus $-\mathrm{NH}_{2}$ tersebut menjadi tidak tersedia lagi untuk berikatan dengan permukaan sel kapang (Li et al., 2008; Park et al., 2008). Dari laporan ini, bisa diduga bahwa telah terbentuk ikatan semu antar gugus aktif $-\mathrm{NH}_{2}$ ketika aplikasi COS dengan konsentrasi lebih besar dari 250 ppm pada $A$. flavus, lebih besar dari 750 ppm pada aplikasi di $A$. niger dan 500 ppm pada aplikasi ke Penicillium A 12. Hasil penelitian lain melaporkan bahwa COS dengan rantai lebih panjang seperti kitooligomer yang berukuran 4,6 kDa atau setara dengan COS 23 rantai, memperlihatkan anti Candida krusei dan menghambat germinasi kapang Fusarium oxysporum (Thikhonov et al., 2006). Panjang rantai dan derajat asetilasi dari COS sangat mempengaruhi potensi antikapang ini, semakin rendah derajat asetilasinya, maka COS tersebut semakin berpotensi sebagai materi antikapang. Dalam penelitian ini, COS yang dihasilkan merupakan campuran berbagai panjang rantai karena yang digunakan adalah enzim kasar. Dari hasil analisis dengan HPLC (Gambar 1) dengan menggunakan standar rantai 1-6 (N-acetyIDglucosamin- hexaosa), COS yang diproduksi dengan enzim kasar Microminospora T5a1 merupakan campuran dari keenam produk tersebut, ditambah dengan kemungkinan COS dengan rantai $>6$ yang tidak dapat terdeteksi dengan menggunakan standar ini.

\section{KESIMPULAN}

Kitooligosakarida (COS) yang dibuat dari kitosan yang dihidrolisis dengan menggunakan enzim kitosanase kasar dari isolat T5a1 memiliki potensi untuk digunakan sebagai anti kapang. Kitooligosakarida tersebut mampu menghambat Aspergillus flavus, Aspergillus niger and Penicillium sp A12 pada konsentrasi berturut turut 250, 750, dan 500 ppm. Kemampuan penghambatan COS tersebut sepadan dengan kemampuan penghambatan oleh sodium benzoat dan potassium sorbat pada konsentrasi komersialnya (1000 ppm). Dibanding dengan bentuk polimernya yaitu kitosan, $\mathrm{COS}$ dengan konsentrasi penghambatan terbaik, memperlihatkan kinerja penghambatan yang lebih baik terhadap $A$. flavus dan $A$. niger lebih baik, tetapi untuk kapang Penicillium A 12, COS memperlihatkan kinerja yang tidak beda dengan kitosan

Penelitian ini mengkonfirmasi hasil penelitian terdahulu yaitu bahwa penghambatan kapang oleh kitosan dan turunannya yaitu COS tidak bersifat linear dengan konsentrasi. Hasil penelitian ini perlu dilanjutkan dengan aplikasi COS secara in vivo yaitu aplikasi pada produk perikanan secara langsung untuk memperkuat hasil in vitro ini atau mengkonfirmasi kesimpulan sementara bahwa COS berpotensi sebagai pengganti materi antikapang komersial potasium sorbat dan sodium benzoat (1000 ppm).

\section{DAFTAR PUSTAKA}

Aam, B.B., Heggset, E.B., Norberg, A.L., Sorlie, M., Varum, K.M., and Eijsink, V.G.H. 2010. Production of chitooligosaccharide and their potential application in medicine. Marine Drugs . 8(5): 1482-1517.

Chasanah, E., Riviyanti, T.A., and Noriko, N. 2011. Produksi oligomer kitosan secara enzimatis dan uji 
bioaktivitasnya terhadap beberapa kapang hasil isolasi dari produk hasil perikanan. Jurnal Pascapanen dan Bioteknologi Kelautan dan Perikanan. 6(2): 139-146.

Chien, J.H., Tang, K.W., Shu, C.C., and Chao, Y.C. 2005. Identification and antifungal chitinases from a potential biocontrol agent, Bacillus cereus 28-9. Journal of Biochemistry and Molecular Biology. 38(1): 82-88.

Indriati, N., Supriadi, M.W., and Salasa FF. 2008. Isolation and identification of mould from boiled-salted skipjack (Euthynnus affinis). Jurnal Pascapanen dan Bioteknologi Kelautan dan Perikanan. 3(1): 29-36

Ariyani, F. And Yennie, Y. 2008. Preservation of boiled salted scad mackerel (Decapterus russelli) using chitosan. Jurnal Pascapanen dan Bioteknologi Kelautan dan Perikanan. 3(2): 139-146

Hardjito, L. 2006. Application of chitosan as food additive and preservation. In Santoso J., Trilaksani W., Nurhayati T. And Suseno SH (eds.). Prosiding Seminar Nasional Kitin-Kitosan 2006. Departemen Teknologi Hasil Perairan. Fakultas Perikanan dan IImu Kelautan, IPB, Bogor. p. 1-13.

Helander, I., Nurmiaho-Lassila, E., Ahvenainen, R., Rhoades, J., and Roller, S. 2001. Chitosan disrupts the barrier properties of the outer membrane of Gramnegative bacteria. Int. J. Food Microbiol. 71: 235-44.

Kim, S.K., Jeon, Y., and Zan, H.C. 2000. Antibacterial effect of chitooligosaccharides with different moleculare weights prepared using membrane bioreactor. J. Chitin Chitosan. 5(1): 1-8.

Kim, Se-Kwon. 2011, Chitin, Chitosan, Oligosaccharides and Their Derivatives: Biological Activities and Applications, CRC Press Taylor \& Francis Group, Boca Raton.

Li, X.F., Feng, X.Q., Yang, S., Wang, T.P., and Su, Z.X. 2008. Effects of Molecular Weight and Concentration of Chitosan on Antifungal Activity Against Aspergillus niger. Iranian Polymer Journal. 17(11): 843-852.

Liu X., Yun L., Dong Z., Zhi L., and Kang, D. 2001. Antibacterial action of chitosan and carboxymethylated chitosan. J. Appl Polym Sci. 79(7): 1324-35.

Mamur, S., Yüzbapýoðlu, D., Ünal, F., and Yýlmaz, S. 2010, Kitooligosakarida Does potassium sorbate induce genotoxic or mutagenic effects in lymphocytes? Toxicology in Vitro. 24(3): 790-794.

Noviendri, D., Fawzya, Y.N., and Chasanah, E. 2008, Karakteristik dan sifat kinetika enzim kitinase dari isolat bakteri T5a1 asal terasi. Jurnal Pascapanen dan Bioteknology Kelautan dan Perikanan. 3(2): 123-129.

Palma-Guerrero, J., Huang, I.C., Jansson, H.B., Salinas, J., Lopez-Llorca, L.V., and Read, N.D. 2009. Chitosan permeabilizes the plasma membrane and kills cells of Neurospora crassa in an energy dependent manner. Fungal Genet. Biol. 46: 585-594.

Park, Y., Kim, M.H., Park, S.C., Cheong, H., Jang, M.K., Nah, J.W., and Hahm, K.S. 2008. Investigation of the antifungal activity and mechanism of action of LMWSchitosan. J. Microbiol. Biotechnol. 18: 1729-1734. 182.

Rhoades, J., and Roller, S. 2000. 'Antimicrobial actions of degraded and native chitosan against spoilage organisms in laboratory media and foods'. Appl. Environ. Microbiol. 66(1): 80-86.

Roller, S. and Covill, N. 1999. The antifungal properties of chitosan in laboratory media and apple juice. Int $\mathrm{J}$ of Food Microbiol. 47(1-2): 67-77.

Shahidi, F., J.K.V. Arachchi, and Jeon, Y.J. 1999. Food applications of chitin and chitosan. Trends Food Sci. Technol. 10: 37-51.

Sebti, I., Martial-Gros, A., Carnet-Pantiez, A., Grelier, S., and Coma, V.J. 2005. Chitosan polymer as bioactive coating and film against Aspergillus niger contamination. J. Food Sci. 70: 100-104.

Sudjana, M.A. 1996. Metoda Statistika. Tarsito: Bandung.

Tikhonov, V.E., Stepnova, E.A., Babak, V.G., Yamskov, I.A., Palma-Guerrero, J., Jansson, H.-B., Lopez-Llorca, L.V., Salinas, J., Gerasimenko, D.V., Avdienko, I.D., and Varlamov, V.P. 2006. Bactericidal and antifungal activities of a low molecular weight chitosan and its $\mathrm{N}$-/2(3)-(dodec-2-enyl)succinoyl/-derivatives. Carbohydr. Polym. 64: 66-72.

Tsai, G-J. and Su, W-H. 1999. Antibacterial activity of shrimp chitosan against Escherichia coli. J. Food Prot. 62: 239-243.

Xie, W., Xu, P., Wang, W., and Liu, Q. 2002. Preparation and antibacterial activity of a water-soluble chitosan derivative. Carbohydrate Polym. 50: 35-40.

Xu, J., Zhao, X., Han, X. and Du, Y. 2006. Antifungal activity of oligochitosan against Phytophthora capsici and other plant pathogenic fungi invitro. Pesticide Biochemistry and Physiology. 87(3): 220-228.

Zambonelli, A., Zechini, A., Aulerio, D., Bianchi, A., and Albasini, A. 1996. Effects of essential oils on phytopathogenic fungi in vitro. J. Phytopath. 144: 4914.

Zhao, X.R., and Xia, W.S. 2006. 'Antimicrobial activities of chitosan and application in food preservation', Chinese Food Research and Development. 27(2): 157-160. 